\title{
The origins and early dispersal of horsegram (Macrotyloma uniflorum), a major crop of ancient India
}

\author{
Dorian Q. Fuller • Charlene Murphy
}

Received: 31 October 2016/ Accepted: 31 May 2017

(C) The Author(s) 2017. This article is an open access publication

\begin{abstract}
Horsegram has been an important crop since the beginning of agriculture in many parts of South Asia. Despite horsegram's beneficial properties as a hardy, multi-functional crop, it is still regarded as a food of the poor, particularly in southern India. Mistakenly regarded as a minor crop, largely due to entrenched biases against this under-utilised crop, horsegram has received far less research than other pulses of higher status. The present study provides an updated analysis of evidence for horsegram's origins, based on archaeological evidence, historical linguistics, and herbarium collections of probable wild populations. Our survey of herbarium specimens provides an updated map of the probable range of the wild progenitor. A large database of modern reference material provides an updated baseline for distinguishing wild and domesticated seeds, while an extensive dataset of archaeological seed measurements provides evidence for regional trends towards larger seed size, indicating domestication. Separate trends towards domestication are identified for northwestern India around $4000 \mathrm{BP}$, and for the Indian
\end{abstract}

Electronic supplementary material The online version of this article (doi:10.1007/s10722-017-0532-2) contains supplementary material, which is available to authorized users.

D. Q. Fuller $(\square) \cdot$ C. Murphy

Institute of Archaeology, University College London, 31-34 Gordon Square, London WC1H OPY, UK e-mail: d.fuller@ucl.ac.uk
Peninsula around $3500 \mathrm{BP}$, suggesting at least two separate domestications. This synthesis provides a new baseline for further germplasm sampling, especially of wild populations, and further archaeobotanical data collection.

Keywords Domestication · Biogeography · Macrotyloma uniflorum - Morphometric · Archaeobotany $\cdot$ Linguistics $\cdot$ South Asia

\section{Introduction}

Horsegram (Macrotyloma uniflorum (Lam.) Verdc. is a hardy pulse crop of semi-arid tropics that has been poorly studied. Despite its current and historical importance to the diet of a large part of the population in India, there are entrenched biases against horsegram, as it is considered a low status food of the poor, particularly in southern India (Kadam et al. 1985; Ambasta 1986, 181). Smartt $(1985,299)$ remarked that " $[\mathrm{t}]$ here has been remarkably little incentive to study domestication and evolution of horse gram". Indeed, very little agronomic research has been done on this crop (Yadav 1992). The limited scientific knowledge of this crop is reflected in its status in textbooks, even those produced in India, its main country of production (Fig. 1). Horsegram has received far less research than pulses of higher status, such as Indian Vigna (V. radiata (L.) Wilczek, $V$. mungo (L.) Hepper) or pigeonpea (Cajanus cajan (L.) 


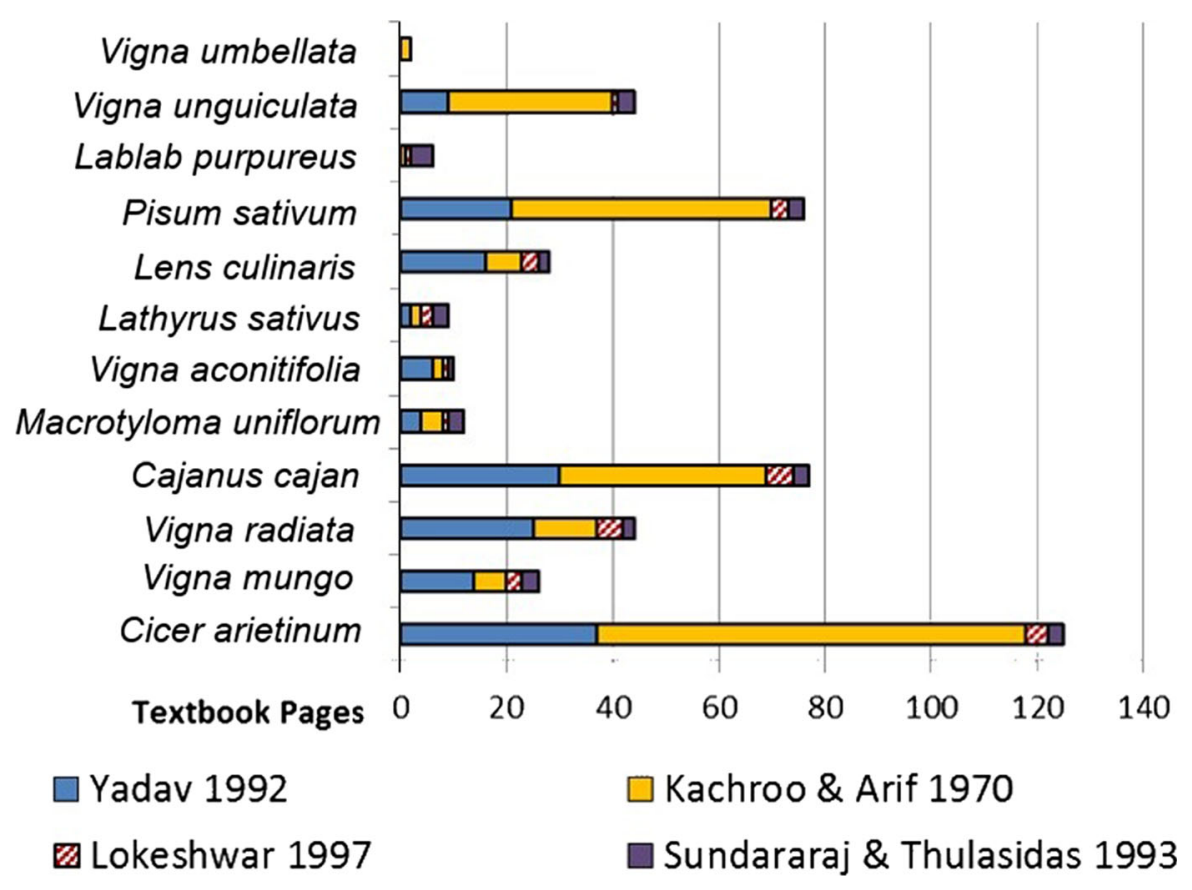

Fig. 1 Quantitative comparison of knowledge based on textbook coverage of Indian pulses in a selection of agricultural reference books published in India (Kachroo and Arif 1970; Yadav 1992; Sundararaj and Thulasidas 1993; Lokeshwar 1997)

Millsp.). Indeed, whilst both the Indian Vigna spp. and Cajanus have received monographic studies of wild relatives (Tomooka et al. 2014; Khoury et al. 2015; Mallikarjuna et al. 2011; van der Maesen 1986) and genetic studies of relationships with wild relatives (Lee 2013; Xu-xiao et al. 2003; Zong et al. 2003; Aruna et al. 2009; Kassa et al. 2012; Saxena et al. 2014). Only recently has small scale genetic research been conducted on horsegram (e.g. Sharma et al. 2015). Horsegram earned its common English name as it has been used as fodder to horses and cattle for centuries (Watt 1889-1893), and less often eaten by the British or higher status Indians; often in India as a supplement to the bulky-straw fodders used (Nezamuddin 1970, 321). Despite such prejudice, horsegram (Macrotyloma uniflorum) ranks among the most important pulse crops of India (Fig. 2).

Indeed, horsegram is the fifth most widely grown pulse species in modern India (Fig. 2). It is amongst the most ubiquitous archaeological pulse finds (Fig. 3), indicating that it has been of widespread importance since the Neolithic period. It is especially important on the Indian peninsula in the Dravidianspeaking states of Tamil Nadu, Karnataka and Andhra Pradesh (Nezamuddin 1970, 321; Sundararaj and Thulasidas 1993, 159). Tamil Nadu and Andhra Pradesh together account for nearly $90 \%$ of the total Indian acreage under this crop. Annual yields of horsegram are low given its area of production, which may be due in part to its use on fields with poor agronomic conditions, but this may also reflect in part a bias against research on and improvement efforts devoted to this crop. It would appear that horsegram's importance declines as one moves north (Lokeshwar 1997). Nevertheless, it is also cultivated, on a smaller scale, in Pakistan, Bangladesh, Nepal, and Myanmar (Spate and Learmonth 1967). It is reported to be grown in the northwest Himalayas up to ca. 2000 meters and in the eastern Himalayas (Sikkim) up to at least 1000 meters (Atkinson 1882; Watt 1889-1893) and in recent times in Australia, Taiwan and the Philippines as a fodder crop. It was introduced in colonial Southeast Asia as a fodder crop (Burkill 1966), although archaeological evidence indicates that it had previously been produced in peninsular Thailand for at least a few centuries, ca. 300 BC-AD 100 (Castillo et al. 2016). This raises the question as to whether cultivation of this crop was formerly more widespread in Southeast Asia. 


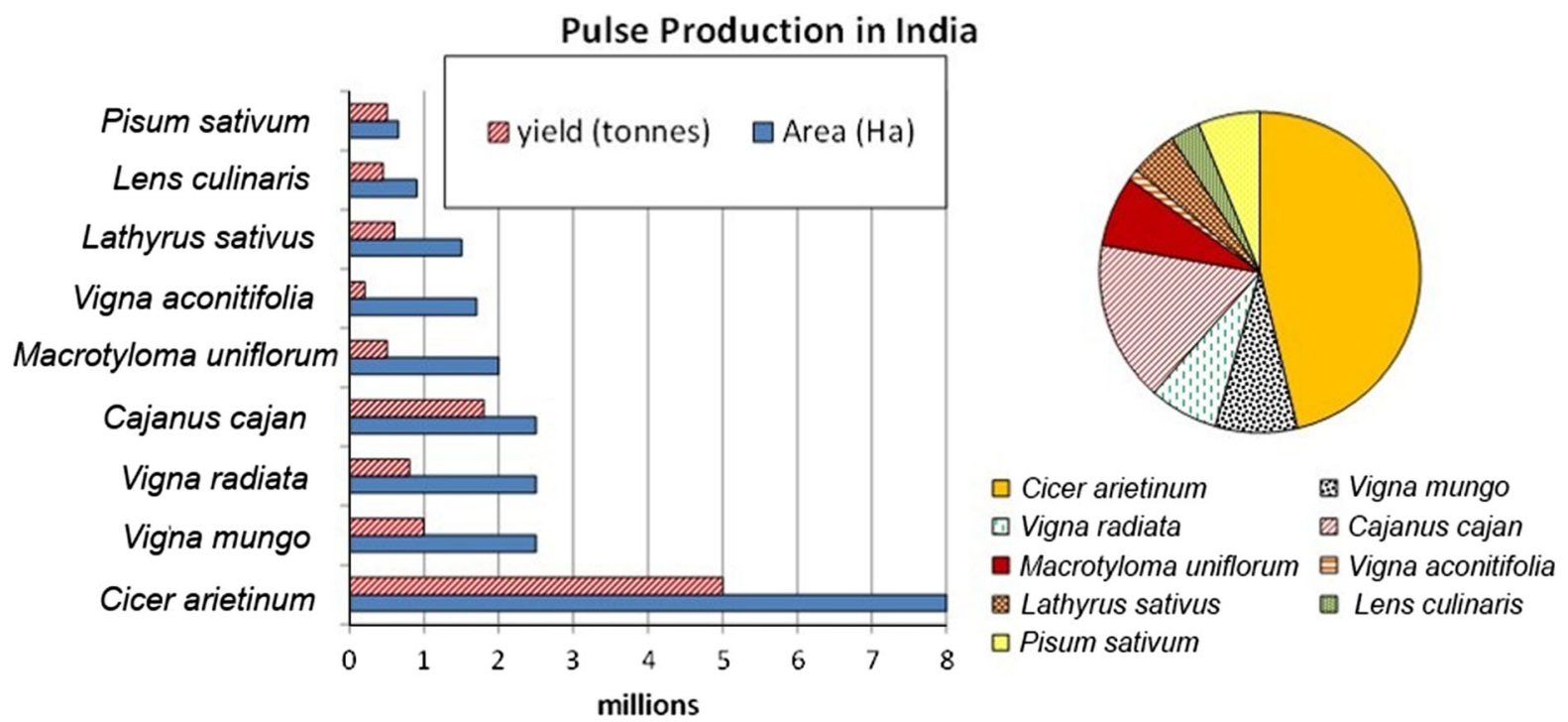

Fig. 2 A comparison of production of nine major pulse crops of India, in terms of estimated area sown and annual yield in tonnes, based on Lokeshwar (1997). Inset: estimated percentage of pulse cultivation area devoted to different species in India according to Randhawa (1958)

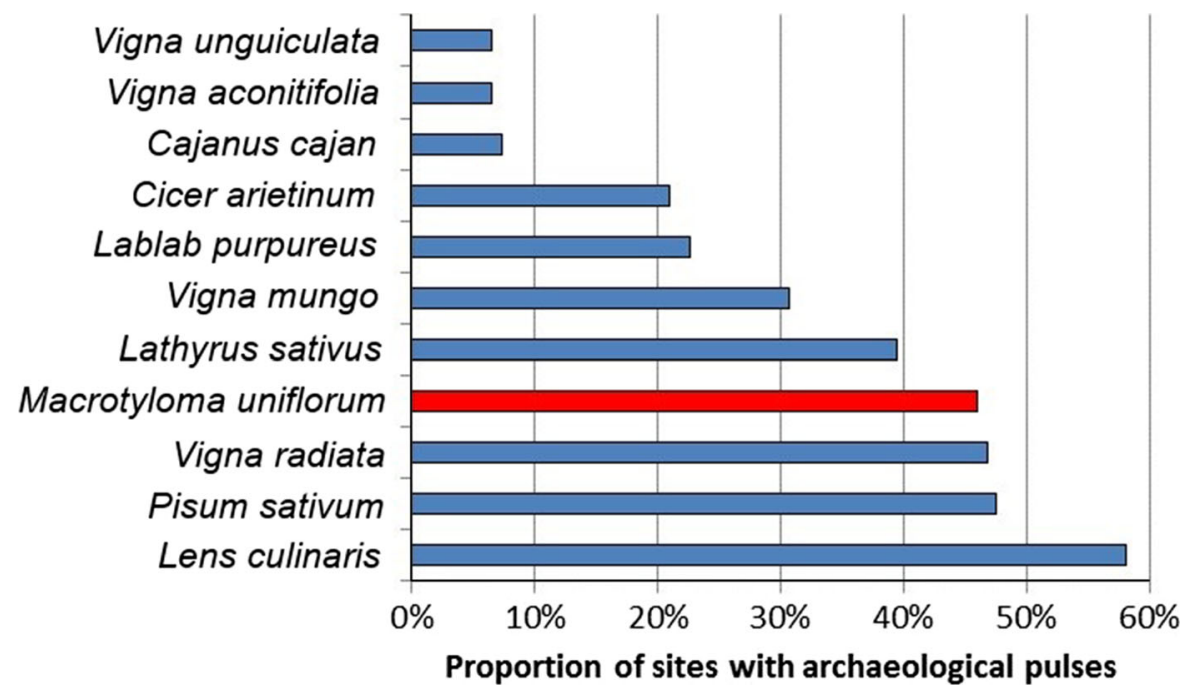

1998, 2008). Nevertheless, an evolutionary and historical perspective on this crop remains to be better developed.

The aim of the present paper is to start to redress the research imbalance of this important crop species by providing a comprehensive assessment of the evidence for the biogeographical dispersal, domestication and importance of horsegram in ancient times. We draw together all the available published archaeobotanical evidence, and provide quantitative evidence for the domestication process of this 
species, and a comparison of modern material. This study provides a baseline for further research into the origins and evolution of domesticated horsegram. In addition, we review inferences from historical linguistics that also highlight the long-term importance of this species in the agricultural systems of India, especially in the South.

Descriptive botany, nutrition and taxonomy

Botanically, Macrotyloma uniflorum, commonly known as horsegram, is an annual herb, growing to a height of 30-40 cm (Neelam et al. 2014, 17; Nezamuddin 1970, 322; Smartt 1985, 12; Sundararaj and Thulasidas 1993, 159). Recent studies on modern germplasm from Andhra Pradesh, India have revealed a wide range of phenotypic variation in this species (Neelam et al. 2014, 17). Unsurprisingly then, based upon its phenotypic plasticity, one of horsegram's most important traits is its tolerance to a wide range of climatic and soil conditions (Kachroo and Arfi 1970; Nezamuddin 1970, 321; Yadav 2002); even growing wild in the astringent soil of the eucalyptus forests of Queensland (Nezamuddin 1970, 322). In southern India horsegram is grown as a dry crop from August to October, in areas with less than $90 \mathrm{~cm}$ of rain annually, and as low as $40 \mathrm{~cm}$, on mostly poor or lateritic soils, usually with no irrigation (Kingwell-Banham and Fuller 2014, 3490; Nezamuddin 1970, 321-322). It is considered native to the drier climatic tracts of India (Asouti and Fuller 2008, 67).

Along with horsegram's catholic growing conditions its main agrarian value lies in its multiple usages: as green manure, as its husks have excellent water retaining capacities (Nezamuddin 1970, 321; Zaman and Mallick 1991); for its good soil retention abilities; its short height allows it to be used as an understory crop, grown under taller crops such as sorghum (Sorghum bicolor (L.) Moench), pearl millet (Pennisetum glaucum (L.) R.Br.) or pigeonpea ( $\mathrm{Ca}$ janus cajan) (Nezamuddin 1970, 321-322). Horsegram may be planted as a preparatory crop on new marginal land due to its nitrogen fixing properties (Nezamuddin 1970, 322) and, advantageously, horsegram is a crop that is relatively free of pests and diseases. All these beneficial traits in this pulse would have secured its place in cultivation since ancient times.
As an edible crop, horsegram is an excellent source of protein, carbohydrates, dietary fibre, and micronutrients (Jacobs and Steffen 2003; Yadav et al. 2004; Sangita et al. 2004). However, horsegram flour usage has been limited due to the presence of certain anti-nutrient effects from phytate, tannins and tryspin inhibitors, which limit its nutrient value (Kawsar et al. 2008a; Sreerama et al. 2012, 462). Horsegram is regarded as having poor functional and expansion properties as a flour (Sreerama et al. 2008, 891), in contrast with several other Indian pulses. However, these same anti-nutrient phtyochemicals are thought to have beneficial medicinal and nutraceutical properties (Muthukumara et al. 2014; Bhartiya et al. 2015; Prasad and Singh 2015). Nevertheless, processing horsegram into commercially viable food products, including composite pulse flour, with cowpea and chickpea, has attracted growing interest from researchers and commercial food manufacturers (Abbas et al. 1984; Sreerama et al. 2012, 467; Khatum et al. 2013).

There has been a degree of taxonomic confusion over horsegram, reflected in the botanical, agronomic as well as the recent archaeobotanical literature of India. Since Joseph Dalton Hooker's Flora of British India (1879), Linnaeus' Dolichos biflorus has been widely used as the scientific name for horsegram, in the India floristics and archaeobotanical literature (e. g. Watt 1908; Gamble 1935; Kajale 1991; Saraswat 1992; Vishnu-Mittre 1989). However, the type material originally used by Linnaeus in 1753 was actually a catjang-type cowpea, now placed in the polytypic species Vigna unguiculata (L.) Walp. (Smartt 1985, 299). Thus, D. biflorus L. is an old synonym for the cowpea, Vigna unguiculata (or Vigna unguiculata subsp. unguiculata), a very different crop, with origins in Africa (D'Andrea et al. 2007; Fuller and Hildebrand 2013).

Unfortunately, this erroneous equation has been wrongly used in some modern literature, leading to apparent reports of African cowpea, where Indian horsegram is clearly implied by figures, descriptions, and English and Hindi names (e.g. Weber 1991; Reddy 1994; Devaraj et al. 1995; Kroll 1996) The archaeological finds traditionally described as $D$. biflorus should in fact be Dolichos uniflorum Lam., or its revised synonym Macrotyloma uniflorum (Lam.) Verdc. (Kingwell-Banham and Fuller 2014, 3490). Transferred from the heterogenous genus Dolichos to 
Macrotyloma in 1970 by the botanist Verdcourt (1970) (Smartt 1985, 298-299), horsegram is now in a genus that includes three economic plants: M. uniflorum, M. axillare (Meyer) Verdcourt (a fodder crop), and M. geocarpum (Harms) Maréchal \& Baudet, the African groundbean or Bambara groundnut (Isely 1983, 492). Thus, Macrotyloma uniflorum (Lam.) Verdc. is used below as the correct synonym for Dolichos uniflorus Lam. and for mislabelled archaeological "Dolichos biflorus" (Fuller 2002; Kingwell-Banham and Fuller 2014, 3490).

Historical linguistics and the hypothesis of peninsular Indian origins

Historical linguistics reconstructs hypothetical ancestral languages based on what is essentially a phylogenetic approach to modern languages, based on shared innovations. This can allow for the reconstruction of words, both their past phonetics and their probable meaning, including the names for plants, for past periods when this is shared across several branches in a language family (e.g. Crowley 1997; Southworth 2005). It is also possible to infer ancient loanwords between languages. In India, except in the high Himalayas, there are three main language families (Indo-European, Austroasiatic [Munda], and Dravidian), and most common names across all of these families suggest a shared ancient name for horsegram, indicating deep cultural roots and ancient cultural knowledge of this crop that was transferred across languages (Fuller 2003, 2007a; Southworth 2005). We briefly summarize these data here, as they suggest an origin of this crop somewhere in the peninsular Indian region, and it can be suggested that knowledge of this crop, or at least its name, was transmitted from the early Dravidian speakers of peninsular India to early Indic languages (including Sanskrit) and Austroasiatic.

Based on regular sound correspondences between and across most Dravidian languages, Southworth (2005) has reconstructed an ancient word for horsegram *kol-or $* k o l-u t$. This is reflected in descended terms in many modern languages (Table 1), while two series of related words can be seen in the Indic languages, a branch of Indo-European, e.g. Sanskrit kulattha, and the Munda group of languages found in the hills of eastern and central India, e.g. juang kulto (Zide and Zide 1976; Fuller 2003; Southworth 2005).
While the phylogeny of the Dravidian languages is reasonably well-established, it is more difficult to infer when different language sub-families diverged and where the speakers of past proto-languages lived. Written sources can help, but for Dravidian languages only Tamil, Kannada and Telugu have old written evidence and most of that is less than 2000 years old (Dravidian languages). Another approach to constraining the timing of divergence is to relate lists of reconstructed vocabulary for material things to when those things are known to be present archaeologically. Thus, for example, reconstructed vocabulary for iron metallurgy cannot date to prior to the Iron Age when such technology was first adopted in a region. In the case of South Dravidian languages, including the ancestral speech to modern Tamil and Kannada, vocabulary for iron metallurgy and textile production, especially from cotton, can be reconstructed (Fuller 2008, 2009). This places this ancestral speech no earlier than ca. 1200 BC, and suggests these languages diverged sometime more than 2000 years ago (i.e. during the Iron Age). Crops provide another useful set of material terms, as their earliest occurrences can be inferred from archaeobotanical data, especially for species that are not native to a region, such as the arrival of wheat and barley in South India, or crops such as sorghum which are of African origin (Fuller 2003, 2007b).

In addition, knowledge of native flora, such as the names of trees can indicate something of the ecological zones with which early language speakers were familiar, and in the case of early Dravidian we can construct several major trees from the moist deciduous, dry deciduous and savanna vegetation of peninsular India (Fuller 2007a; Asouti and Fuller 2008). In addition, the familiarity of proto-Dravidian speakers with several kinds of pottery indicates that this whole language differentiated since the Neolithic when pottery first developed in India (Southworth 2005; Fuller 2009). Thus, while Southworth (2005) had inferred a lower Godavari valley origin for Dravidian, based on the geographical centre of language diversity, the tree vocabulary suggests somewhere around the margins of Deccan plateau, no further north or west than Gujarat and Rajasthan (Fuller 2007a). This fits with the hypothesis that the Neolithic of southern India dispersed with early pastoralism (and pottery) from Gujarat through the open woodlands of the Deccan starting ca. 3000 BC 
Table 1 Linguistic evidence for horsegram in South Asia. Sources: Turner (1966), Burrow and Emeneau (1984), Zide and Zide (1976), Ambasta (1986), Southworth (2005), Witzel (2009)

\begin{tabular}{|c|c|c|c|}
\hline Family/subfamily & Language & Names & $\begin{array}{l}\text { Historical linguistic shared } \\
\text { reconstructions/comments }\end{array}$ \\
\hline \multirow{6}{*}{$\begin{array}{l}\text { Dravidian } \\
\text { South Dravidian }\end{array}$} & Tamil & kol & Proto-Dravidian $* k o / * k o l-u t$ \\
\hline & & & \\
\hline & Malayalam & kolḷu & \\
\hline & Tulu & kuḍi & \\
\hline & Koraga & koṇne & \\
\hline & Kanada & hurali & \\
\hline \multirow[t]{6}{*}{ South-Central Dravidian } & Gondi (Mu.) & kore $\tilde{\bar{e}}$ & \\
\hline & Gondi (Ma.) & kori & \\
\hline & Gondi (Ko.) & kore & \\
\hline & Kui & koraka & \\
\hline & Kuwi & kora & \\
\hline & Telugu & ulavalu & \\
\hline \multirow[t]{2}{*}{ Central Dravidian } & Parji & kol & \\
\hline & Gadaba & Kolut, kolup & \\
\hline \multirow[t]{15}{*}{ Indic } & Sanskrit & kulattha- & $\begin{array}{l}\text { Old Indo-Ayran *khalá- kula } \\
\text { (loan from Dravidian?) }\end{array}$ \\
\hline & Pali & kulattha & \\
\hline & Shina (Dardic) & kulát & \\
\hline & Kashmiri & krŏtha & \\
\hline & Punjabi & kulth & \\
\hline & Sindhi & kultho & \\
\hline & Nepali & kulthi & \\
\hline & Bengali & Kulath/kurtikalai & \\
\hline & Assamese & cepetakalai & \\
\hline & Oriya & kulatha & \\
\hline & Bihari & kurthī & \\
\hline & Hindi & kulthī & \\
\hline & Gujarati & kalthī & \\
\hline & Marathi & kulith/muthiva & \\
\hline & Sinhalese & kalat & \\
\hline \multirow{3}{*}{$\begin{array}{l}\text { Munda } \\
\text { North Munda }\end{array}$} & Santali & hora'c & Proto-Munda *kodaXj \\
\hline & & & (loan from Dravidian?) \\
\hline & Ho & hər̆oo & \\
\hline \multirow[t]{7}{*}{ South Munda } & Juang & korto/kulto & \\
\hline & Kharia & kora'j & \\
\hline & Gutob & ga?a & \\
\hline & Remo & ga?a & \\
\hline & Gta? & holcet & \\
\hline & Gorum & goyo & \\
\hline & Sora & șroramakulto & \\
\hline
\end{tabular}


(Fuller 2011). A more westerly Indian origin also fits with more recent arguments that Proto-Dravidian languages are more distantly related to the Elamite languages of the Iranian plateau (Southworth and McAlpin 2013). Horsegram would perhaps be among the earliest cultivars of the Dravidian speaking Neolithic of peninsular India, alongside native millets like Brachiaria ramosa (L.) Stapf. and the mungbean (Vigna radiata) (Fuller et al. 2004).

Archaeological and botanical evidence for origins

Archaeobotanically, Macrotyloma is widely reported from Chalcolithic and Neolithic sites, with candidates for the earliest occurrences from Khujhun, in the Vindhyan plateau (Kajale 1991; Saraswat 1992), the Harappan site of Burthana Tigrana in Haryana (Willcox 1992) and Southern Neolithic sites of Andhra and Karnataka (Fuller et al. 2011; Kajale 1991, 1998). Thus, this pulse is well represented by archaeological finds across India, from the mid or late third millennium BC onwards. However, the regional origins of this pulse have been obscure as wild progenitor populations have been poorly studied in South Asia, and have never been described in the floristic studies of India (Fuller 2002). Nevertheless, Fuller and Harvey (2006) inferred a likely South Indian origin, and perhaps a separate northwest Indian origin based on the distribution of archaeobotanical evidence and a limited assessment of herbarium specimens from the Botanical Survey of India, Pune. The Haryana region, Gujarat region, south Deccan are all plausible foci of early cultivation or domestication (Kingwell-Banham and Fuller 2014, 3492).

\section{Materials and methods}

The present study expands upon this earlier work through three lines of evidence. First, we have surveyed further herbarium specimens of likely wild progenitor's populations held in herbarium collections from Kew and the London Natural History Museum (Fig. 4). These provide some augmentation of the distribution of wild populations, which can be combined with the extent of climatic conditions similar to where these have been found. Second, we provide an extensive baseline study of seed size in modern domesticated and wild horsegram, which provides a basis from which to infer the domesticated status of archaeological horsegram based on seed measurements. Third, we summarize current seed size data from archaeological specimens which allows us to infer the time period(s) of horsegram domestication in or near likely regions of origin (Fig. 5). Fourth, we provide an updated database on the archaeological occurrence of horsegram in time and space (Fig. 6) which allows us to identify those regions in which it occurs earliest and are therefore more likely be at or close to the region (s) of initial cultivation and domestication.

Herbarium collections of Macrotyloma were surveyed including those from South Asia and from Africa. In 2004 one of us (DQF) studied collections held in the Botanical Survey of India herbaria in Pune and Calcutta, which provided 6 localities in India, mostly associated with the drier savanna belt, where wild horsegram had been collected (Fuller and Harvey 2006). This is augmented in the current study by 31 additional occurrences (see results, below). $M$. uniflorum var. stenocarpum (Brenan) Verdc. are by definition wild specimens, but we also included those that had been identified as M. uniflorum var. uniflorum but have dehiscent (wild-type) pods and/or occurred in wild rather than in cultivated habitats. In addition, where seeds were visible on the herbarium specimen, or loose in attached pouches, these were measured. While Macrotyloma uniflorum occurs wild in Africa, and three subspecies have been described (Verdcourt 1970, 1971), these have never apparently been domesticated. Therefore, their seed metrics provide a useful baseline for wild size range which augments the more limited materials of wild horsegram from India.

Morphometric measurements were undertaken on the length, width (Fig. 5), thickness and hilum length of modern populations of horsegram, including all 3 wild subspecies (M. uniflorum var. stenocarpum (Brenan) Verdc., M. uniflorum var. verrucosum Verdc., and $M$. uniflorum var. benadirianum (Choiv.) Verdc.) and also sister species of horsegram including $M$. axillare (E. Mey.) Verdc., M. ciliatum (Willd.) Verdc., from several reference collections including UCL, Mediterranean and Near Eastern Reference Collection, Royal Botanic Gardens, Kew, Economic botany collection 
Fig. 4 Herbarium specimen originally labelled as Dolichos biflorus with seeds in pouch (Image can be found at http://specimens.kew.org/ herbarium/K001092968)

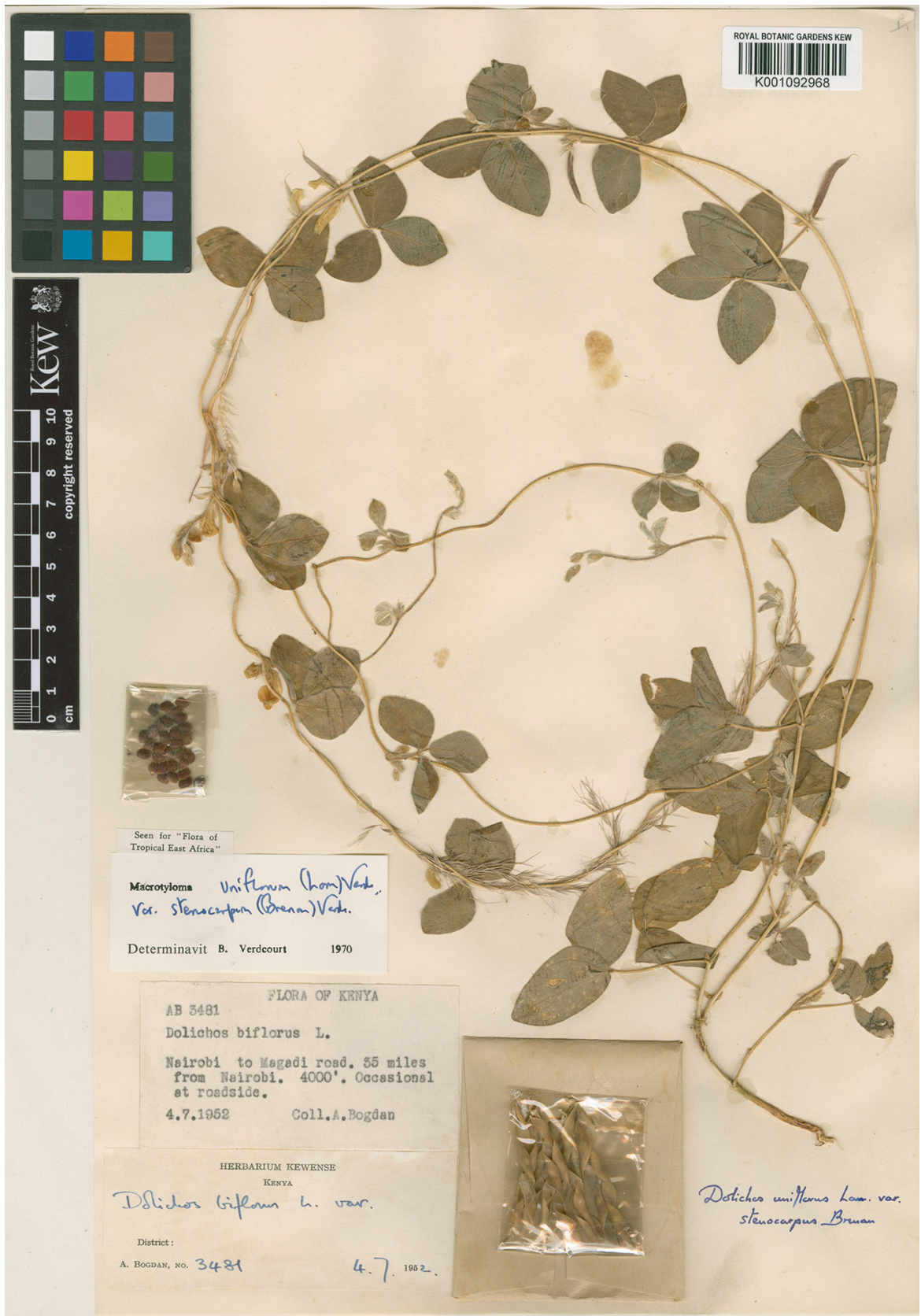

and herbarium specimens, along with additional requested germplasm kindly supplied by the USDA (Table 2). We have gathered from the literature all the available published measurements of archaeological horsegram and have augmented these with measurements from our own archaeological collections (Table S6). Further analysis of archaeological seed metrics is currently ongoing and will be fully published elsewhere (Murphy and Fuller, in prep.)

\section{Results}

Distribution and ecology of wild horsegram

Wild horsegram has received little attention from botanists working in India or from crop geneticists. However, relatively recently a separate species, Macrotyloma sar-garhwalensis has been proposed as a new species by Gaur and Dangwal (1997), although 


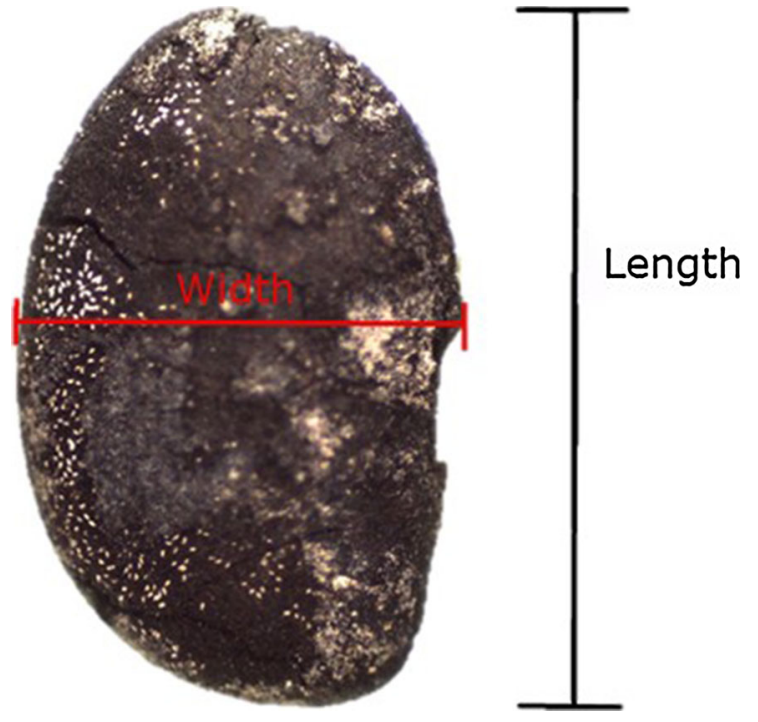

Fig. 5 Measurements taken using archaeological specimens of horsegram for length $(\mathrm{mm})$ of the longest point and width $(\mathrm{mm})$ across the hilum at the widest point

its scientific name is still considered unresolved (www.theplantlist.org). It was found and named after the type locality of the village of Sara of Garhwal Himalaya (Pauri District) Uttarakhand, India. It is commonly found near edges of crop fields (Gaur and Dangwal 1997, 283; Gaur 1999), and can be expected up to elevations of about 1500 meters. Germplasm collections, for example that of the USDA, include only cultivated material, and while we relied on this extensively for measurements, we have had to turn to older herbarium collections, both to infer where wild populations have been encountered in the past and to provide measurements on wild seeds (Table 3). We can now provide the following updated map of wild occurrences in India (Fig. 7), shading indicates areas that might be considered as ecologically plausible zones for wild horsegram now or in the past, prior to habitat destruction through agricultural occupancy and pastoralism. The wild habitat of horsegram appears to be in the dry evergreen open woodlands (Acacia and Albizzia dominated), which represents India's savannah vegetation (Asouti and Fuller 2008). It is in similar bioclimatic zones where wild Macrotyloma uniflorum is reported in Africa (Verdcourt 1971). As horsegram is an excellent fodder crop, it is likely that the spread of domesticated animals since the Neolithic has greatly reduced wild populations. In addition, in the recent Flora of Mizoram M. uniflorum is noted as a "common species in open places" (Singh et al. 2002, 485), and as this is not described as cultivated it is possible that some wild population extend to north-eastern India and even to adjacent Myanmar. On the other hand, it is also possible that these represent feral populations derived from ancient crops. Targeted fieldwork to study wild horsegram is still needed (Fuller 2002, 485).

Macrotyloma metrics: a modern baseline for domestication studies

Domestication in horsegram, as in other pulses, should involve loss of wild seed dispersal, i.e. retention of seeds in pod through non-dehiscence, loss of seed dormancy and germination inhibition,

Table 2 Modern specimens of horsegram measured

\begin{tabular}{llr}
\hline Number of modern specimens measured & Collections & N \\
\hline Macrotyloma axillare & UCL (ex USDA) & 402 \\
M ciliatum & Kew & 11 \\
M. uniflorum var. stenocarpum & Kew & 51 \\
M. uniflorum var. stenocarpum & BSI & 4 \\
M. uniflorum var. verrucosum & Kew & 16 \\
M. uniflorum var. benadirianum & Kew & 18 \\
M. uniflorum var. uniflorum & UCL & 358 \\
M. uniflorum var. uniflorum & UCL (ex USDA) & 13 \\
M. uniflorum var. uniflorum & Kew & 328 \\
Total & & 1497 \\
\hline
\end{tabular}

Further details of measured specimens in Table S1 


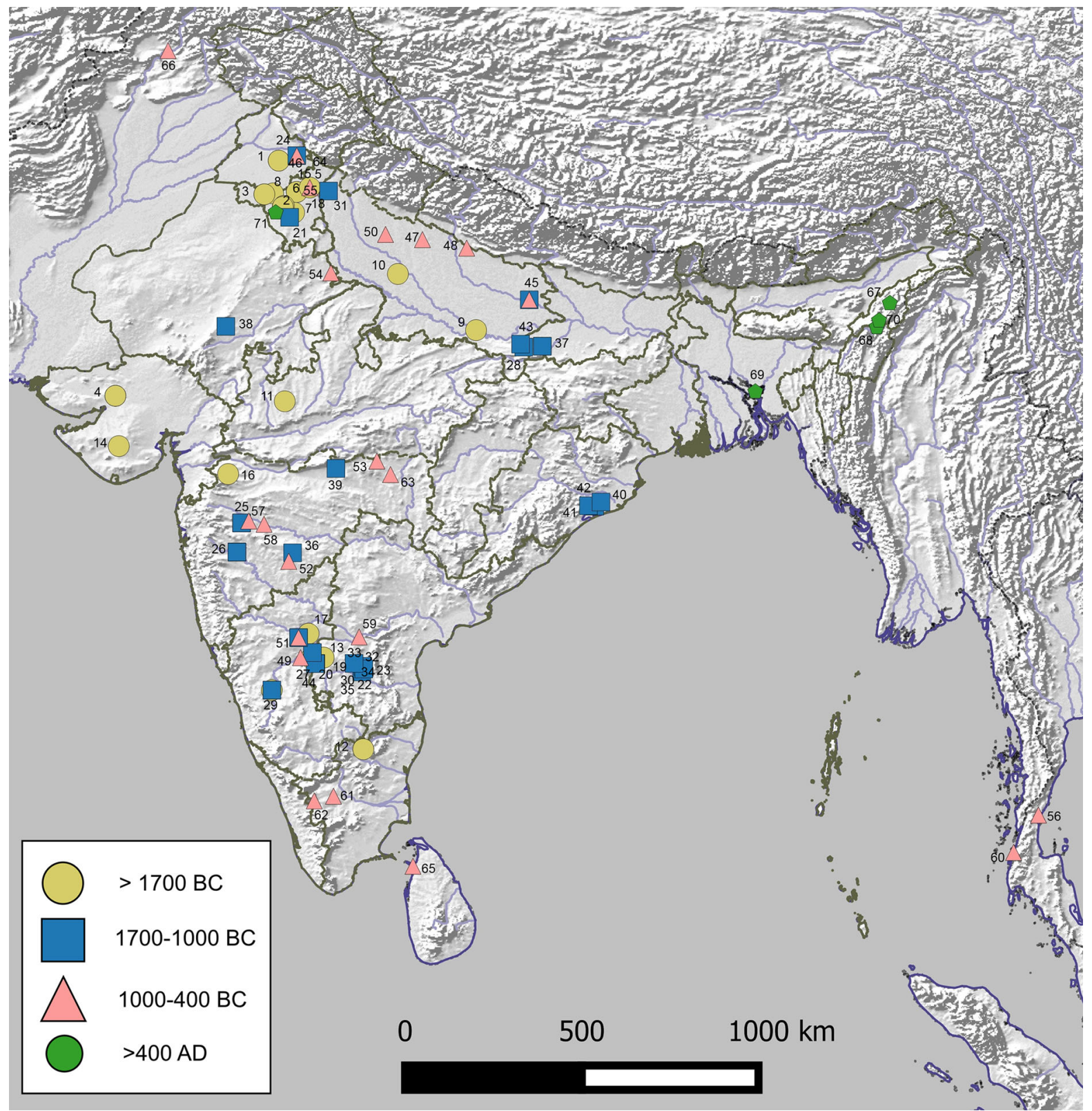

Fig. 6 Map of identified archaeological horsegram in South Asia (Table S4 for further details). Sites numbered: 1 Rohira 2 Masudpur VII 3 Banawali 4 Kanmer 5 Balu 6 Kunal 7 Farmana 8 Masudpur VII 9 Jhusi 10 Ahirua Rajarampur 11 Kayatha 12 Paiyampalli 13. Hallur 14 Rojdi 15 Bahola 16 Kaothe 17 Watgal 18 Bahola 19 Hattibelagallu 20 Kurugodu, 21 Mitathal 22 Hiregudda 23 Sanganakallu 24 Sanghol 25 Daimabad 26 Inamgaon 27 Piklihal IIIA 28 Senuwar 29 Hallur 30 Hanumantaraopeta 31 Hulas 32 Injedu 33 Peddamudiyam 34
Singanapalle 35 Tekkalakota 36 Apegaon 37Tokwa 38 Ojiyana 39 Tuljapur Garhi 40 Golbai Sassan 41 Gopalpur 42 Harirajpur 43 Malhar 44 Piklihal IIIB 45 Narhan, 46 Bahola 47 Charda 48 Narhan 49 Kadebakele 50 Ahichchhatra, 51 Piklihal IIIB/IV 52 Ter (Thair) 53 Adam 54 Noh 55 Saunphari 56 Khao Sam Kheo 57 Paithan I 58 Nevasa 59 Veerapuram 60 Phu Khao Thong 61 Kodumanal 62 Perur 63 Bhagimohari 64 Sanghol 65 Mantai 66 Hund, 67 Chungliyimti 68 Khezhakeno 69 Vikrampura 70 Khusomi 71 Ludwala (Mangali Ludwala), 72 Loteshwar 
Table 3 Wild Populations of horsegram examined

\begin{tabular}{|c|c|c|c|c|c|}
\hline Collection & Species & Subspecies & Country & State: locality & Habitat \\
\hline Drummond 24623 (Kew) & M. uniflorum & var. uniflorum & India & Punjab & $\begin{array}{l}\text { Jungle; free-growing, wild/ } \\
\text { weedy characters }\end{array}$ \\
\hline Drummond 24620 (Kew) & M. uniflorum & var. uniflorum & India & Punjab & $\begin{array}{l}\text { Jungle; free-growing, wild/ } \\
\text { weedy characters }\end{array}$ \\
\hline Drummond 24624 (Kew) & M. uniflorum & var. uniflorum & India & Punjab & $\begin{array}{l}\text { Jungle; free-growing, wild/ } \\
\text { weedy characters }\end{array}$ \\
\hline Remanandan 4298 (Kew) & M. uniflorum & var. uniflorum & India & Madhya Pradesh & $\begin{array}{l}\text { Free-growing, wild/weedy } \\
\text { characters }\end{array}$ \\
\hline Remanandan 4597 (Kew) & M. uniflorum & var. uniflorum & India & Madhya Pradesh & $\begin{array}{l}\text { Free-growing, wild/weedy } \\
\text { characters }\end{array}$ \\
\hline van der Maesen 2833 (Kew) & M. uniflorum & var. uniflorum & India & $\begin{array}{l}\text { Himachal } \\
\text { Pradesh: } \\
\text { Bharwain }\end{array}$ & $\begin{array}{l}\text { Pine forest, sandy soil (PH 6), } \\
650 \mathrm{~m} \text { asl; free-growing, } \\
\text { wild/weedy characters }\end{array}$ \\
\hline van der Maesen 3463 (Kew) & M. uniflorum & var. uniflorum. & India & Kerala & $\begin{array}{l}\text { Scrub jungle, } 470 \mathrm{~m} \text { asl; free- } \\
\text { growing, wild/weedy } \\
\text { characters }\end{array}$ \\
\hline Mooney 2364 (Kew) & M. uniflorum & var. stenocarpum & India & Orissa & $\begin{array}{l}\text { Climbing among bushes not } \\
\text { far from fields }\end{array}$ \\
\hline Haines 173P (Kew) & M. uniflorum & var. stenocarpum & India & $\begin{array}{l}\text { Central } \\
\text { Provinces }\end{array}$ & Wild, woods \\
\hline Rich 409 (Kew) & M. uniflorum & var. stenocarpum & India & Himalayan & \\
\hline Collett 596 (Kew) & M. uniflorum & var. stenocarpum & India & & Waterfalls, 5000 feet \\
\hline Mooney 3673 (Kew) & M. uniflorum & var. stenocarpum & India & Orissa & $\begin{array}{l}\text { Dry jungles, among quartzite } \\
\text { rocks, } 2200 \mathrm{ft} \text {. }\end{array}$ \\
\hline $\begin{array}{l}\text { Stocks (Herb. Hookerianum) } \\
\text { (Kew) }\end{array}$ & M. uniflorum & var. stenocarpum & India & & \\
\hline Remanandan 4560 (Kew) & M. uniflorum & var. stenocarpum & India & Madhya Pradesh & \\
\hline van? Soest L200 (Kew) & M. uniflorum & var. verrucosum & Kenya & $\begin{array}{l}\text { Mombasa-Voi } \\
\text { Rd. }\end{array}$ & \\
\hline Magogo \& Glover 200 (Kew) & M. uniflorum & var. verrucosum & Kenya & Kwale Dist & \\
\hline Polhill \& Paulo 886 (Kew) & M. uniflorum & var. verrucosum & Kenya & Kilifi Dist. & $\begin{array}{l}\text { Sandy soil between forest and } \\
\text { mangrove swamp }\end{array}$ \\
\hline $\begin{array}{l}\text { Gilbert \& Gachathi } 5243 \\
\text { (Kew) }\end{array}$ & M. uniflorum & var. verrucosum & Kenya & & $\begin{array}{l}\text { Steep slope with massive } \\
\text { granite outcrops, in crevices }\end{array}$ \\
\hline Greenway 9268 (Kew) & M. uniflorum & var. benadirianum & Kenya & & \\
\hline Bogdan 3481 (Kew) & M. uniflorum & var. stenocarpum & Kenya & Nairobi & \\
\hline Bally \& Smith B14649 (Kew) & M. uniflorum & var. stenocarpum & Tanzania & & Roadside weed \\
\hline Gillett 18580 (Kew) & M. uniflorum & var. stenocarpum & Kenya & Kitui District & $\begin{array}{l}\text { Granite-gneiss outcrops with } \\
\text { derived sandy soil; } \\
\text { savannah shrub/tree veg. }\end{array}$ \\
\hline Welwitsch 2212 (BM) & M. uniflorum & var. stenocarpum & Angola & Loanda Dist. & \\
\hline Jain 46660 (BSI) & M. uniflorum & var. stenocarpum & India & Maharashtra & \\
\hline
\end{tabular}

Collection refers to collection number of herbarium specimens and standard herbarium abbreviation. The locations of these taxa are plotted in Fig. 7, with further details in Table S5

and changes in seed dimensions (Zohary et al. 2012, 76; Smartt 1990; Fuller 2007b). Pods, however, have never been recovered archaeologically. Changes in seed coat thickness that might relate to dormancy require further study (Murphy and Fuller 2017). Another related domestication trait that we observed 
Fig. 7 Map of distribution of wild populations of horsegram based upon data from Table 5 (and Table S4), and including $M$. sar-garhwalensis

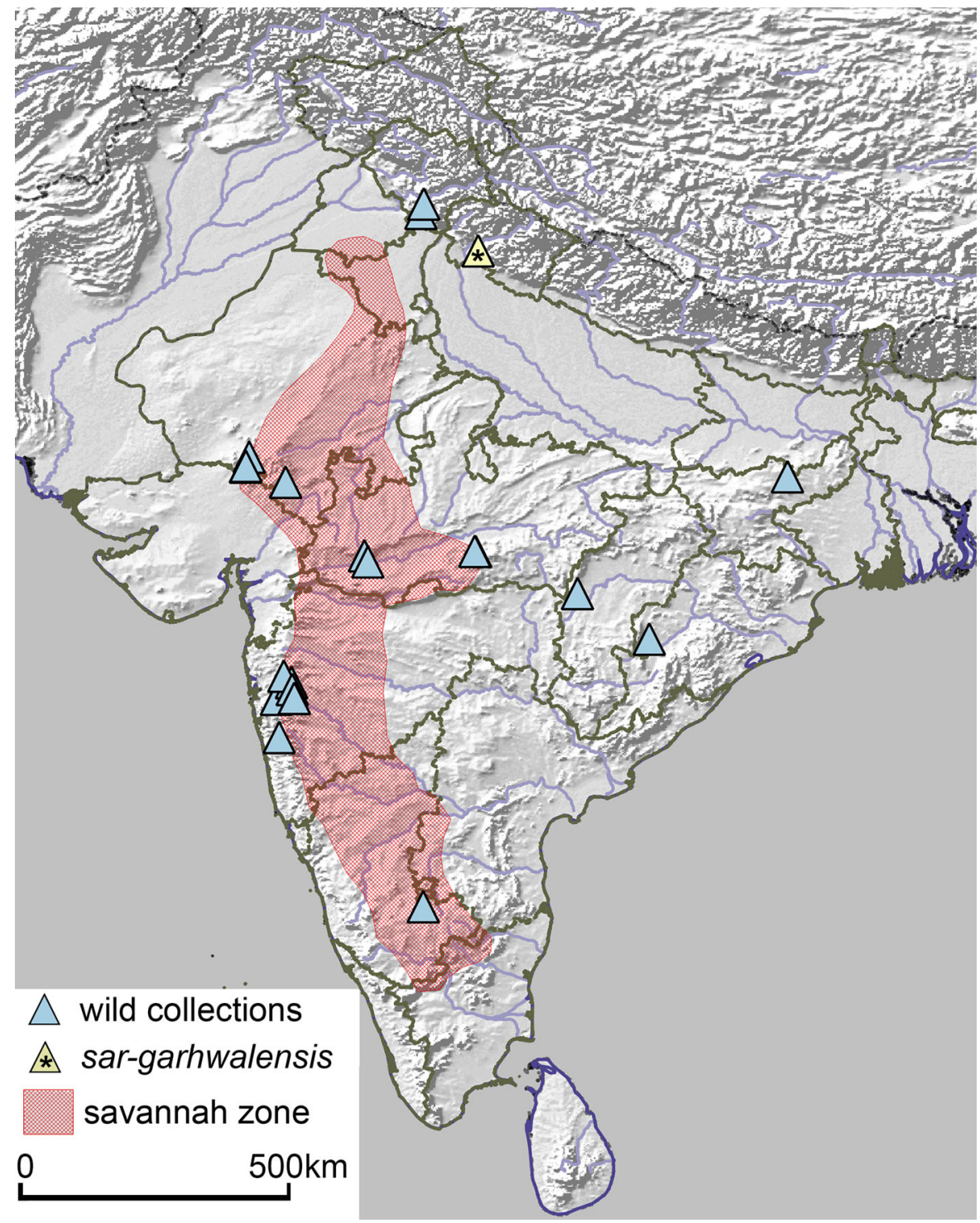

in modern collections is testa colour. Modern horsegram populations show polymorphism in terms of testa colours which include non-cryptic testa colours, red and white, and mottled patterns whilst wild populations have uniformly black to very dark brown seeds. However, because the archaeological grains are preserved by charring they all appear black and the original colour is not preserved. As far as we can determine under light microscopy and scanning electron microscopy the changes in colour do no correlate with any obvious structural changes in the seed coat, and therefore this cannot be used to examine domestication in archaeological finds.
Therefore, of all these traits, grain size increase is currently the most tractable archaeobotanical trait (Fig. 8).

Details of modern seed metrics

Morphometric measurements of modern specimens showed a great deal of intra-species variation, which could be accounted for due to the large geographical area under study. Wild modern specimens of Macrotyloma axillare, M. uniflorum var. stenocarpum, and M. uniflorum var. verrucosum showed a much smaller seeds size than modern domesticated 


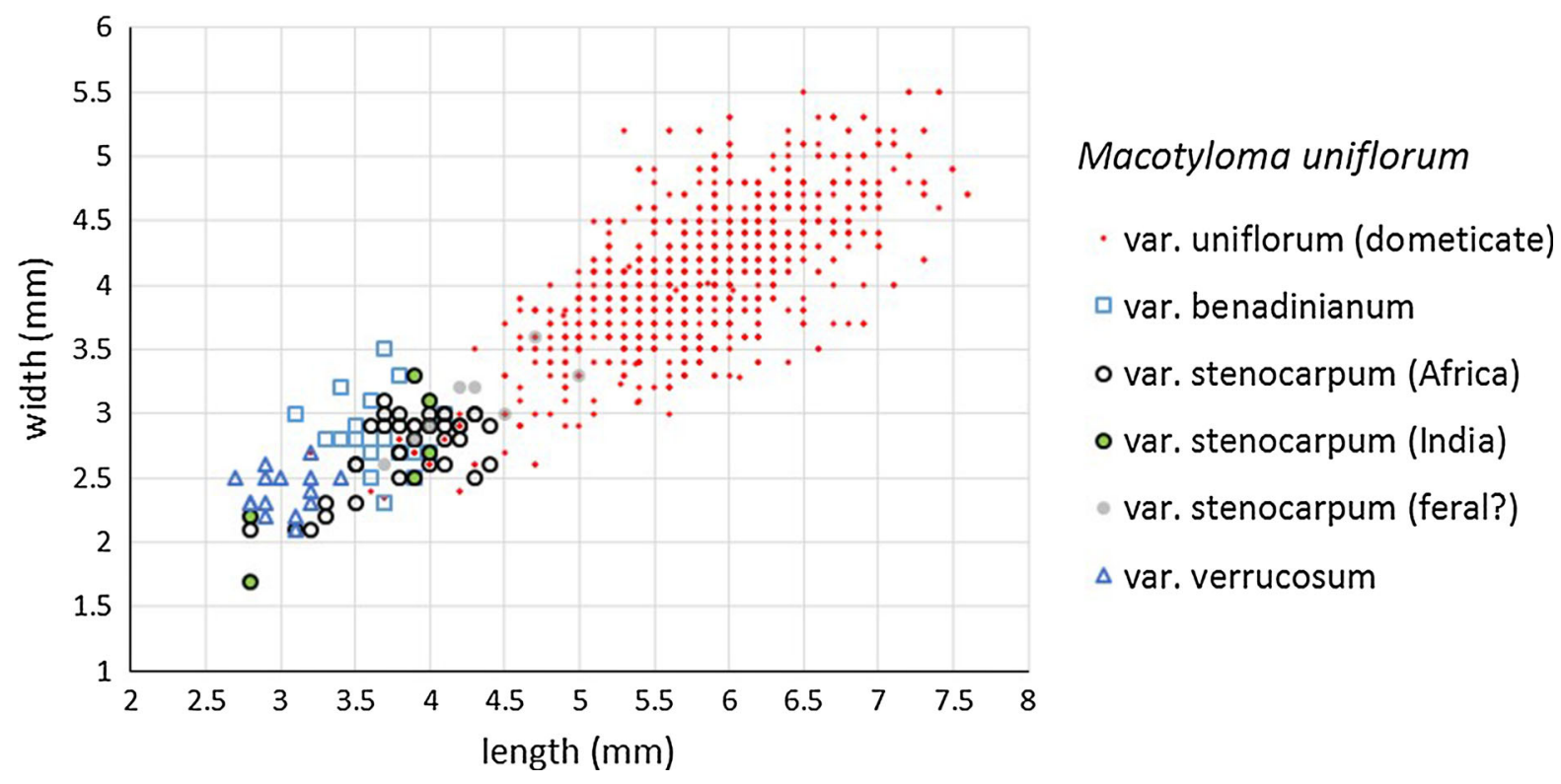

Fig. 8 Scatterplot of modern Macrotyloma seeds, width (mm) plotted by length (mm)

horsegram as expected (Fig. 9). If the comparison is restricted to the wild subspecies of $M$. uniflorum versus domesticated forms, overlap between the two forms is minimal and separation is feasible.

Seed metrics and pulse domestication in India

There have been discussions as whether size increase occurs during the initial stages of domestication (Purugganan and Fuller 2009, 2011). Recent comparative studies suggest that in general seed size increases in pulses and other seed crops occurs during the same domestication episode that saw the evolution of domestication traits (Fuller et al. 2014; Moles et al. 2007). Nevertheless, in South Indian mungbeans (Vigna radiata) seed size increase is marked in the Second Millennium BC (Fuller 2011; Fuller et al. 2014), and occurs after the introduction of mungbeans to the Ganges valley in this period (Fuller and Harvey 2006; Fuller 2007a, 903, 915-916). Although mungbeans were present earlier in the eastern Harappan zone, available data on seed size suggests that these were already enlarged and fully domesticated, whereas the mung beans initially introduced to the Ganges plain were still small-seeded and in the wild size range, like those in the earlier Neolithic/ Chalcolithic of the Deccan. It can be suggested that a separate trend of seed enlargement for mung bean took place in the Ganges region slightly faster than the late Neolithic domestication processes documented in South India (Fuller and Harvey 2006).

Distribution of archaeological horsegram

Wild horsegram (Macrotyloma uniflorum var. stenocarpum) is native to the Acacia thickets ranging from the Aravalli hills in Rajasthan, through Gujarat and the savannahs of the Southern Peninsula (Asouti and Fuller 2008; Fuller and Murphy 2014), as well as the margins of dry deciduous woodlands, possibly extending to hills in central and eastern India (Fig. 7). It may be that these wild progenitors of horsegram were more widespread during the mid-Holocene climatic wet phase. A key unresolved question is whether wild horsegram population ever extended west into the Saurashtra peninsula region, south of the Thar Desert and west of the Aravalli hills. A subsequent reduction of their availability, during the aridification that began in the later Fourth Millennium BC (Ponton et al. 2012; Prasad et al. 2014), may be connected to their domestication and the emergence of the Southern Neolithic; as these hunter/gatherer/foragers began to collect and artificially concentrate patches of horsegram in their seasonal 

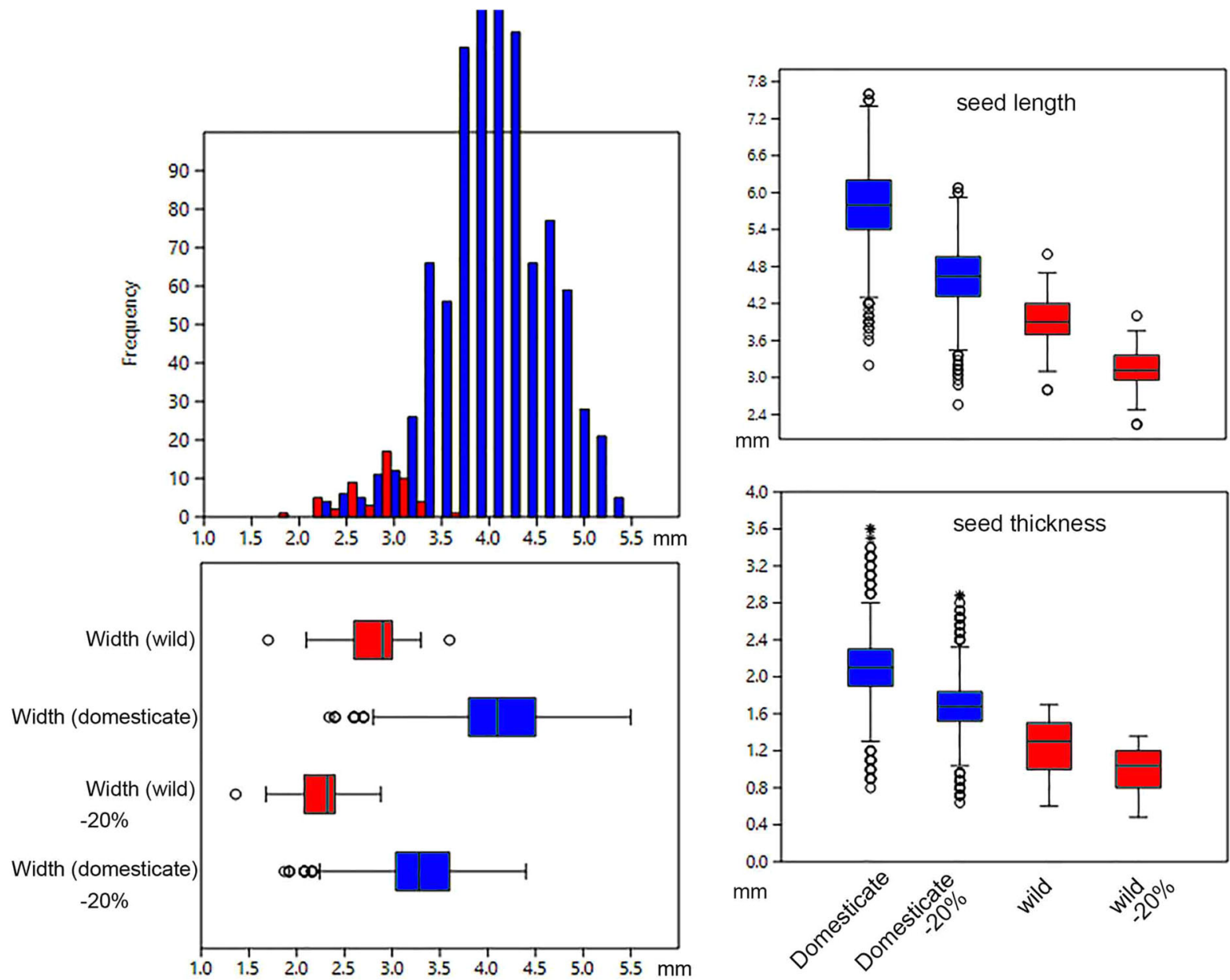

Fig. 9 Frequency histogram of seed width measurements in wild seeds $($ light/red $)(\mathrm{n}=86)$ versus domesticated seeds (dark/blue) $(\mathrm{n}=1000)$. Box plots compare width, length and thickness of seeds of wild versus domesticated forms; also shown are measurements adjusted for $20 \%$ shrinkage to approximate the effects of charring, the main form of archaeological preservation. (Color figure online)

part of the Third Millennium BC (García-Granero et al. 2016). Of note is that this site fall outside our expected distribution of wild Macrotyloma uniflorum var. stenocarpum. While it is possible that wild populations did extend through Saurashtra in the past, as this region does have a dry deciduous tropical and savannah flora in common with the Deccan, on current evidence this could indicate an early translocation into Gujarat from wild habitats further east. If so, despite the small size of this find (see Table S2) it can be regarded as a potential early cultivar. The third focus of early finds is in the South Deccan Neolithic. While most finds in this region are securely dated only to after $2000 \mathrm{BC}$, horsegram was found at 
Watgal which was occupied as early as $2800 \mathrm{BC}$ onwards (Fuller et al. 2007). Unfortunately, the stratigraphic contextual position of these finds within Watgal are not reported, and as the site has a long sequence (until perhaps $1000 \mathrm{BC}$ ), how ancient this horsegram was, remains unclear.

Recent archaeobotanical sampling in the Deccan plateau of South India, a large, arid region featuring rich Neolithic period remains (Fuller 2002; Fuller et al. 2004, 2007a, b; see also, Bellwood 2005; Balter 2007) has shown that some of the earliest Southern Neolithic crop domesticates appear to have been locally domesticated. One of the staple crops of the Southern Neolithic (which falls within the territory of the modern states of Karnataka, Andhra Pradesh, and parts of Tamil Nadu) is the native domesticate horsegram (Fuller 2011; Fuller et al. 2014). In this region, published measurements have been augmented by our own measurements of specimens from Tekkalakota, sites of the Kunderu River, and Gopalpur (Fig. 10). What these data indicate is that seed length and width are smaller in the earliest populations and appear to increase around the middle of the Second Millennium $\mathrm{BC}$, suggesting a domestication that started by at least

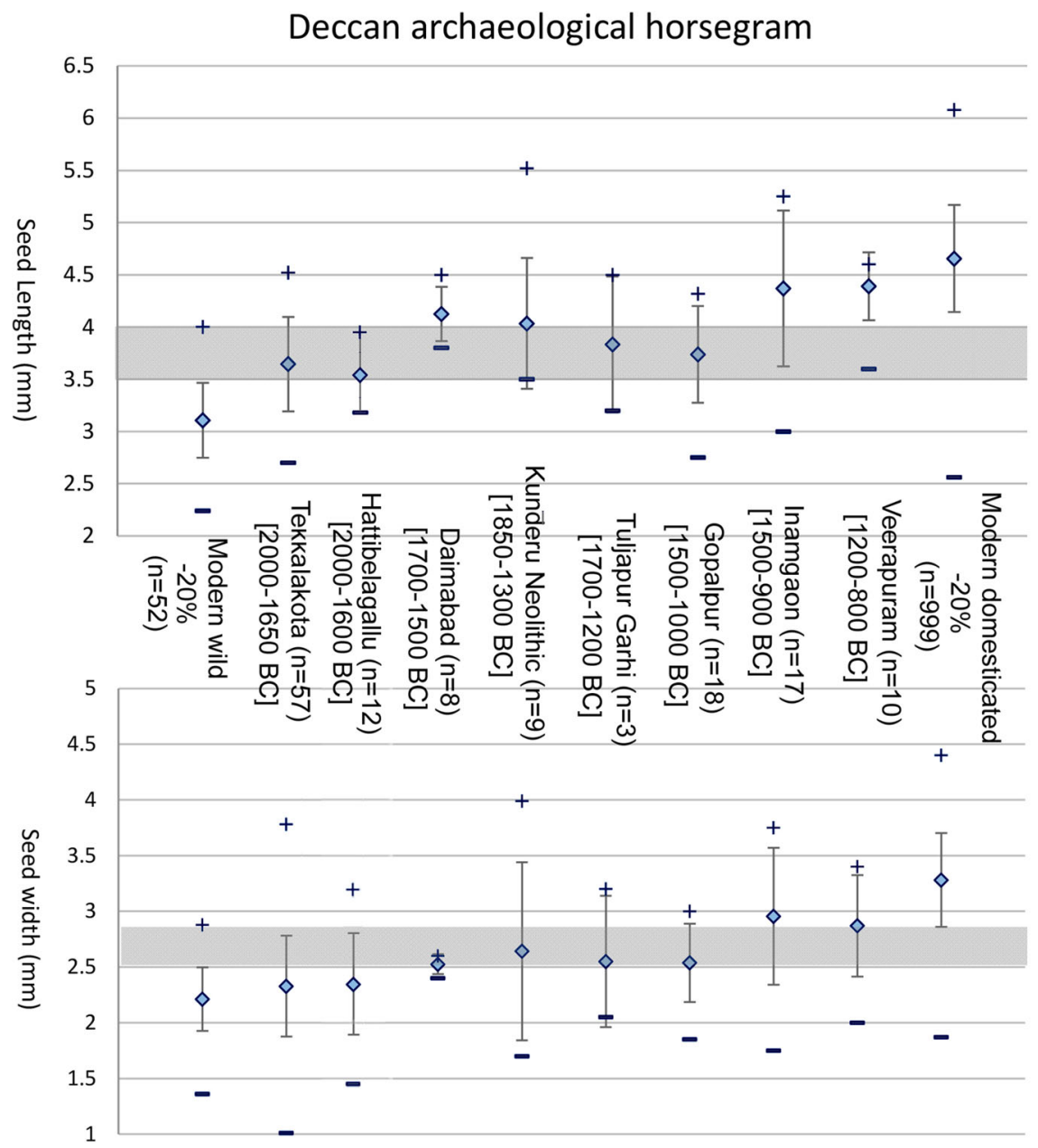

Fig. 10 Seed size (length, top, and width, bottom) in archaeological assemblages of horsegram (Macrotyloma uniflorum) from the Deccan Plateau region of India, including eastern India (Odisha state), indicating mean, standard deviation, maximum recorded size $(+)$ and minimum recorded size $(-)$. All archaeological specimens are preserved carbonized (by charring). Modern wild and domesticated comparisons are given with a correction factor of $-20 \%$ to account for the probable effects of charring. Grey zone indicates the overlap zone of the largest $32 \%$ of wild specimens and the lower end of the domesticated range, and thus provides a visual baseline against which to judge increases in size over time. Dataset summarized in Table S6. (Color figure online) 
4000 years ago. Size increase is evident by around 3500 years ago $(1500 \mathrm{BC})$ and finished by 3000 years ago (1000 BC). Golbai Sassan from eastern India (Odisha) is included on this graph, although it lies in a culturally distinct geographical zone, but could relate to dispersal of early cultivars from the Deccan.

In the Upper Indo-Gangetic alluvium, including the state of Haryana, the earliest known agricultural settlements date to the Early Harappan period, starting by ca. 3000-2800 BC, and the archaeobotanical evidence suggests that winter and summer crops were already both part of the agricultural system at such sites (e.g., Kunal, Balu, Banawali, Masudpur), which included horsegram. Finds are also fairly frequent during the Mature Harappan period (2600$2000 \mathrm{BC}$ ) in this region, and available metrics, such as those from Balu suggest that these may be marginally larger on average than expected for wild populations, indicating that domestication processes had begun (Fig. 11). In the Ganges basin, the introduction of winter crops from the Indus valley included wheat and barley, lentils, as well as some pulses of Indian origin, including horsegram, which are present sometime around 2000-1800 BC (Fuller

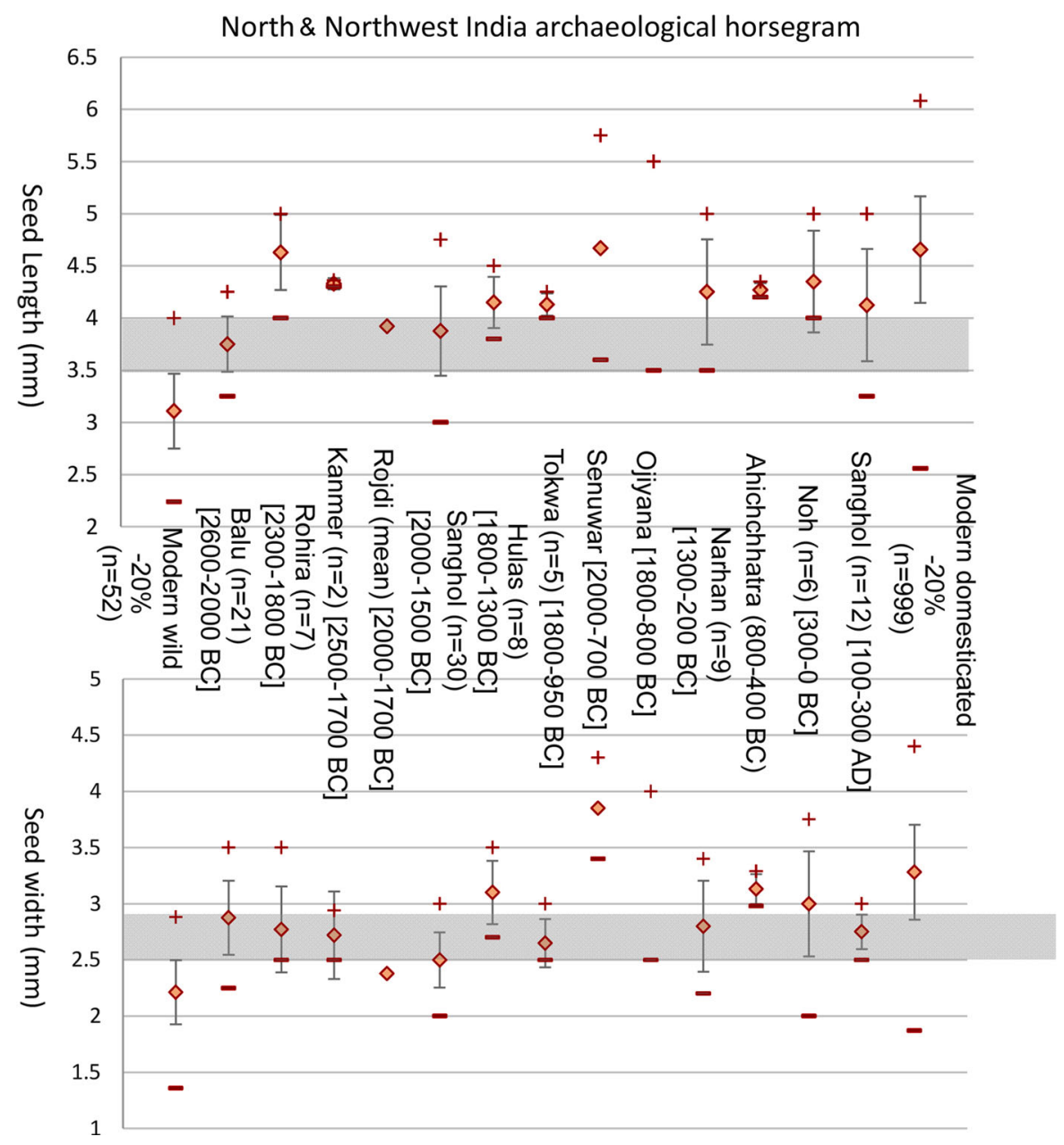

Fig. 11 Seed size (length, top, and width, bottom) in archaeological assemblages of horsegram (Macrotyloma uniflorum) from Northern and Northwest India, including eastern India (Odisha state), indicating mean, standard deviation, maximum recorded size $(+)$ and minimum recorded size $(-)$. All archaeological specimens are preserved carbonized (by charring). Modern wild and domesticated comparisons are given with a correction factor of $-20 \%$ to account for the probable effects of charring. Grey zone indicates the overlap zone of the largest $32 \%$ of wild specimens and the lower end of the domesticated range, and thus provides a visual baseline against which to judge increases in size over time. Dataset summarized in Table S6 
2011), and livestock (sheep, goat and zebu cattle). Fuller (2011) previously suggested that mungbean (Vigna radiata) in the Ganges might have been introduced from the Deccan to the south, although dispersal from Haryana to the west is equally possible. Horsegram metrics from this region, as well as those from the western states of Gujarat and Rajasthan, indicate that trends towards size increase were underway before 2000 BC (Fig. 11). The timing of size increase appears to be finished somewhat earlier in the northwest, compared to South India, and this distinct trend suggests that the domestication process was separate and may have begun earlier in north-western India, perhaps from wild populations in the western Himalayas that were brought down to Indo-Gangetic plains in the Haryana region for cultivation.

\section{Discussion}

Our review of the evidence, leaves no doubt that horsegram (Macrotyloma uniflorum) was domesticated in ancient India. The evidence of remnant wild populations today suggest that the wild progenitors were distributed in the semi-arid savannah or scrub woodland zones, including margins of tropical dry deciduous woodlands, of western and peninsular India, and also through parts of the lower slopes of the western Himalayas. This suggests two main wild distribution areas that were geographically separated, one in the savannah corridor of western and peninsular India, and one in the western Himalayas. A similar disjunct distribution has been identified for wild mungbean (Vigna radiata var. sublobata), although the latter occurs in wetter habitats (moist deciduous woodlands) (Fuller and Harvey 2006; Fuller 2007a, b). In the case of mungbean two distinct domestication trajectories have been inferred, one in northwest India and one in the South (Fuller and Harvey 2006; Fuller 2011). The data presented in the present paper suggests a similar pattern in horsegram. In north-western India, seed size increase took place during the Harappan to Late Harappan periods, whereas in South India it took place over the course of the Second Millennium BC during the later Southern Neolithic/Deccan Chalcolithic (Figs. 10, 11). These two domestication episodes can be suggested to derive from the disjunct wild progenitor populations, and we would therefore predict distinct genetic differences between wild and crop specimens studied with genomic techniques. Limited modern genetic data suggest two groups of horsegram (Sharma et al. 2015), although it is not clear whether these relate to distinct origins. More broadly, syntheses on the origins of agriculture in India recurrently find evidence for likely independent centres of plant domestication in north-western India and South India (Fuller 2011; Fuller and Murphy 2014; KingwellBanham et al. 2015). In the case of South India, seed size increase in horsegram appears to start later (ca. 1500 BC) (Fuller 2011; Fuller et al. 2014), and this could be indicative of cultivation and domestication of horsegram starting earlier. This makes sense considering archaeological evidence that the Neolithic in peninsular India was initially focused on the driest savannah habitats highly suited to pastoralism (Murphy and Fuller 2016), and only subsequently did farmers push into adjacent tropical moist deciduous zones where mungbean was wild (Kingwell-Banham and Fuller 2012). The status of early horsegram in western Gujarat, whether available from the wild or cultivated remains unresolved.

As we have demonstrated in this paper, horsegram has a long history of use in South Asia, although it has received disproportionately little research. Wild populations appear to be rare, possibly endangered, in India, and ought to be the focus of collecting, as these have potential to expand the genetic basis of horsegram improvement. Horsegram's derided status as a crop of the poor needs to be re-evaluated in the light of modern economic and agrarian realities and its potential medicinal, utility and nutritional properties. Today, horsegram is grown across tropical Africa, South Asia, Southeast Asia, China, the Americas and Australia (Kingwell-Banham and Fuller 2014, 3490), although outside of South Asia it is largely used as fodder and within South Asia it is often relegated to consumption by the poorer classes. As one of India's most ancient indigenous pulses as well as one of its most stress tolerant, further research on the origins, diversification and improvement of this species can be expected to contribute to future agricultural sustainability.

Acknowledgements Our current research on domestication is part of the Comparative Pathways to Agriculture Project (ComPAg) funded by a European Research Council advanced 
Grant (No. 323842). Thanks to Dr. Gwilym Lewis, Head of the Legume team, Herbarium, Royal Botanic Gardens, Kew for his kind assistance and access to collections, and to Dr. Mark Nesbit for assistance with and access to the Economic Botany collection, Royal Botanic Gardens, Kew, and to staff at the London Natural History Museum, herbarium department. Thanks to the United States Department of Agriculture (USDA) for providing modern seed samples of Macrotyloma uniflorum and Macrotyloma axillare for this study.

\section{Compliance with ethical standards}

Conflicts of interest The authors declare no conflicts of interest.

Human participants/animals context This research did not involve human participants or animals.

Open Access This article is distributed under the terms of the Creative Commons Attribution 4.0 International License ( http://creativecommons.org/licenses/by/4.0/), which permits unrestricted use, distribution, and reproduction in any medium, provided you give appropriate credit to the original author(s) and the source, provide a link to the Creative Commons license, and indicate if changes were made.

\section{References}

Abbas el Faki H, Venkataraman LV, Desikachar HSR (1984) Effects of processing on the in vitro digestibility of proteins and carbohydrates in some Indian legumes. Qual Plant Plant Foods Hum Nutr 34:127-133. doi: 10.1007/BF01094840

Ambasta SP (ed) (1986) The useful plants of India. Council for Scientific and Industrial Research, New Delhi

Aruna R, Manohar Rao D, Sivaramakrishnan S, Reddy LJ, Bramel P, Upadhyaya H (2009) Efficiency of three DNA markers in revealing genetic variation among wild $\mathrm{Ca}$ janus species. Plant Genet Resour Charact Util 7(2):113121. doi:10.1017/s1479262108061479

Asouti E, Fuller DQ (2008) Trees and woodlands of South India. Walnut creek, California: archaeological perspectives. Left Coast Press, San Francisco

Asouti E, Fuller D, Korisettar R (2005) Vegetation context and wood exploitation in the Southern Neolithic: preliminary evidence from wood charcoals. In: Franke-Vogt U, Weisshaar, H-J (eds) South Asian archaeology 2003, Proceedings of the 17th international conference of the European Association of South Asian Archaeologists (711 July 2003, Bonn), Linden Soft/Verlag, Aachen, Linden, pp 335-340

Atkinson ET (1882) The economic botany of the Himalayas. Cosmo Publications, Delhi (1980 reprint)

Balter M (2007) Seeking agriculture's ancient roots. Science 316:1830-1835. doi:10.1126/science.316.5833.1830

Bates J (2015) Social organisation and change in bronze age South Asia: a multi-proxy approach to urbanisation, deurbanisation and village life through phytolith and macrobotanical analysis. Ph.D. Dissertation, Cambridge University

Bellwood P (2005) The first farmers. Blackwell, Oxford

Bhardwaj J, Yadav SK (2012) Comparative study on biochemical parameters and antioxidant enzymes in a drought tolerant and a sensitive variety of horsegram (Macrotyloma uniflorum) under drought stress. Am J Plant Physiol 7(1):17. doi:10.3923/ajpp.2012.17.29

Bhardwaj J, Mohammad H, Yadav SK (2010) Computational identification of microRNAs and their targets from the expressed sequence tags of Horsegram (Macrotyloma uniflorum (Lam.) Verdc.). J Struct Funct Genom 11:233240. doi:10.1007/s10969-010-9098-3

Bhardwaj J, Chauhan R, Swarnkar MK, Chahota RK, Singh AK, Shankar R, Yadav SK (2013a) Comprehensive transcriptomic study on horse gram (Macrotyloma uniflorum): De novo assembly, functional characterization and comparative analysis in relation to drought stress. BMC Genom 14:647. doi:10.1186/1471-2164-14-647

Bhardwaj J, Mahajan M, Yadav SK (2013b) Comparative analysis of DNA methylation polymorphism in drought sensitive (HPKC2) and tolerant (HPK4) genotypes of horse gram (Macrotyloma uniflorum). Biochem Genet 51:493-502. doi:10.1007/s10528-013-9580-2

Bhartiya A, Aditya JP, Kant L (2015) Nutritional and remedial potential of an underutilized food legume horsegram (Macrotyloma uniflorum): a review. JAPS 25(4):908-920

Bolbhat SN, Dhumal KN (2009) Induced macromutations in Horsegram (Macrotyloma uniflorum (Lam.) Verdc. Legume Res 32(4):278-281

Burkill JH (1966) A dictionary of economic products of the Malay Peninsula. Government of Malaysia and Singapore, Kuala Lumpur

Burrow T, Emeneau MB (1984) A dravidian etymological dictionary, 2nd edn. Clarendon Press, Oxford

Castillo C, Bellina B, Fuller DQ (2016) Rice, beans and trade crops on the early maritime silk route in Southeast Asia. Antiquity 90(353):1255-1269. doi: 10.15184/aqy.2016.175

Crowley T (1997) An introduction to historical linguistics, 3rd edn. Oxford University Press, Oxford

D'Andrea AC, Kahlheber S, Logan AL, Watson DJ (2007) Early domesticated cowpea (Vigna unguiculata) from Central Ghana. Antiquity 81:686-698. doi: 10.1017/s0003598x00095661

Devaraj DV, Shaffer JG, Patil CS (1995) Balasubramanya (1995) The Watgal excavations: an interim report. Man Environ 20(2):57-74

Dhumal KN, Bolbhat SN (2012) Induction of genetic variability with gamma radiation and its applications in improvement of horsegram. Gamma Radiat. doi: $10.5772 / 37885$

Dikshit N, Katna G, Mohanty CS, Das AB, Sivaraj N (2014) Horse Gram. Broadening the genetic base of grain legumes. Springer, New Delhi, pp 209-215

Fuller DQ (2002) Fifty years of archaeobotanical studies in India: laying a solid foundation. In: Settar S, Korisettar R (eds) Indian archaeology in retrospect. Archaeology and interactive disciplines. Manohar, New Delhi, pp 247-364 
Fuller D (2003) An agricultural perspective on Dravidian historical linguistics: Archaeological crop packages, livestock and Dravidian crop vocabulary. In: Bellwood P, Renfrew C (eds) Assessing the languaging/farming dispersal hypothesis. McDonald Institute for Archaeological Research Monographs, Cambridge, pp 191-213

Fuller DQ (2006) Agricultural origins and frontiers in South Asia: a working synthesis. J World Prehist 20(1):1-86. doi:10.1007/s10963-006-9006-8

Fuller DQ (2007a) Non-human genetics, agricultural origins and historical linguistics in South Asia. In: Petraglia MD, Allchin B (eds) The evolution and history of human populations in South Asia. Springer, Amsterdam, pp 393443

Fuller DQ (2007b) Contrasting patterns in crop domestication and domestication rates: recent archaeobotanical insights from the Old World. Ann Bot 100(5):903-924. doi: $10.1093 / \mathrm{aob} / \mathrm{mcm} 048$

Fuller DQ (2008) The spread of textile production and textile crops in India beyond the Harappan zone: an aspect of the emergence of craft specialization and systematic trade. In: Osada T, Uesugi A (eds) Linguistics, archaeology and the human past occasional paper 3, indus project. Research Institute for Humanity and Nature, Kyoto, pp 1-26

Fuller D (2009) Silence before sedentism and the advent of cash-crops: a revised summary of early agriculture in South Asia from plant domestication to the development of political economies (with an excursus on the problem of semantic shift among millets and rice). In: Osada T (ed) Linguistics, archaeology and the human past. Manohar, Delhi, pp 147-187

Fuller DQ (2011) Finding plant domestication in the Indian subcontinent. Curr Anthropol 52(SUPPL. 4):S347-S362. doi: $10.1086 / 658900$

Fuller D (2011) South Asia: archaeology. In: Bellwood PS (ed) The encyclopedia of global human migration. doi: 10.1002/9781444351071

Fuller DQ, Harvey EL (2006) The archaeobotany of Indian pulses: identification, processing and evidence for cultivation. Environ Arch 11(2):219-246. doi: $10.1179 / 174963106 \times 123232$

Fuller DQ, Hildebrand L (2013) Domesticating plants in Africa. In: Mitchell P, Lane P (eds) The Oxford Handbook of African Archaeology. Oxford University Press, Oxford, pp 507-525

Fuller DQ, Korisettar R (2004) The vegetational context of early agriculture in South India. Man Environ XXIX(1):727

Fuller DQ, Murphy C (2014) Overlooked but not forgotten: India as a center for agricultural domestication. Gen Anthropol 21(2):4-8. doi:10.1111/gena.01001

Fuller DQ, Korisettar R, Vankatasubbalah PC, Jones MK (2004) Early plant domestications in southern India: some preliminary archaeobotanical results. Veg Hist Archaeobot 13:115-129. doi:10.1007/s00334-004-0036-9

Fuller DQ, Boivin N, Korisettar R (2007) Dating the Neolithic of South India: new radiometric evidence for key economic, social and ritual transformations. Antiquity 81 (313):755-778. doi:10.1017/S0003598X00095715

Fuller DQ, Boivin N, Hoogervorst T, Allaby R (2011) Across the Indian Ocean: the prehistoric movement of plants and animals. Antiquity 85(328):544-558. doi: 10.1017/s0003598x00067934

Fuller DQ, Denham T, Arroyo-Kalin M, Lucas L, Stevens CJ, Qin L, Allaby RG, Purugganan MD (2014) Convergent evolution and parallelism in plant domestication revealed by an expanding archaeological record. PNAS 111 (17):6147-6152. doi:10.1073/pnas. 1308937110

Gamble JS (1935) Flora of the Madras presidency. Adlard \& Son, London

García-Granero JJ, Lancelotti C, Marco M, P. Ajithprasad, (2016) Millets and Herders: The Origins of Plant Cultivation in Semiarid North Gujarat (India). Current Anthropology 57(2):149-173

Gaur R (1999) Flora of the district Garhwal North West Himalaya (with ethnobotanical notes). TransMedia, Srinagar (Garhwal)

Gaur RD, Dangwal LR (1997) A new species of Macrotyloma (Wight \& Arn.) Verdc. (Fabaceae) from Garhwal Himalaya, U.P. India. J Bombay Nat Hist Soc 94:381-383

Hooker D (1879) Flora of British India. L. Reeve, London

Isely D (1983) A revision of Macrotyloma (Leguminosae). Econ Bot 37(4):492. doi:10.1007/bf02904215

Jacobs DRJ, Steffen LM (2003) Nutrients, foods, and dietary patterns as exposures in research: a framework for food synergy. Am J Clin Nutr 78:508S-513S

Kachroo P, Arif M (1970) Pulse crops of India. Indian Council of Agricultural Research, New Delhi

Kadam SS, Salunkhe DK, Maga JA (1985) Nutritional composition, processing, and utilization of horse gram and moth bean. Crit Rev Food Sci Nutr 22(1):1-26. doi: 10.1080/10408398509527407

Kajale MD (1991) Current status of Indian palaeoethnobotany: introduced and indigenous food plants with a discussion of the historical and evolutionary development of Indian agriculture and agricultural systems in general. New light on early farming- recent developments in palaeoethnobotany. Edinbugh University Press, Edinburgh, pp 155-189

Kajale MD (1998) Initial palaeethnobotany results from Neolithic Watgal, South Indian in relation to data from contemporary sites. In: Unpublished abstract for 11th international work group for palaeoethnobotany, Toulouse, France, 18-23 May 1998

Kassa MT, Penmetsa RV, Carrasquilla-Garcia N, Sarma BK, Datta S, Upadhyaya HD, Varshney RK, von Wettberg EJB, Cook DR (2012) Genetic patterns of domestication in pigeonpea (Cajanus cajan (L.) Millsp.) and wild $\mathrm{Ca}$ janus relatives. PLoS ONE 7(6):e.39563. doi: 10.1371/journal.pone.0039563

Kawsar SMA, Huq E, Nahar N (2008a) Cytotoxicity assessment of the Aerial parts of Macrotyloma uniflorum Linn. Int J Pharm 4(4):297. doi:10.3923/ijp.2008.297.300

Khatum A, Rahman M, Kabir S, Akter MN, Chowdhury SA (2013) Phytochemical and pharmacological properties of the methanolic extract of Ardisia humilis Vahl. (Myrsinaceae). Int J Res Ayurveda Pharm 4(1):38-41. doi: 10.7897/2277-4343.04120

Khoury CK, Bernau V, Ramírez-Villegas J, Castañeda-Alvarez NP, Kassa MT, Jarvis A, Norton SL, Struik PC, Achicanoy HA, van der Maesen L, Jos G (2015) Crop wild relatives of pigeonpea [Cajanus cajan (L.) Millsp.]: distributions, ex situ conservation status, and potential 
genetic resources for abiotic stress tolerance. Biol Conserv 184:259-270. doi:10.1016/j.biocon.2015.01.032

Kingwell-Banham E, Fuller DQ (2012) Shifting cultivators in South Asia: expansion, marginalisation and specialisation over the long term. Quat Int 249:84-95. doi: 10.1016/j.quaint.2011.05.025

Kingwell-Banham E, Fuller DQ (2014) Horse gram: origins and development. Encyclopedia of global archaeology. Springer, NewYork

Kingwell-Banham E, Petrie C, Fuller DQ (2015). Early agriculture in South Asia. In: Barker G, Goucher C (eds) The Cambridge World History, vol 2. A World with Agriculture, 12,000 BCE-500 CE. Cambridge: Cambridge University Press, pp 261-288

Kroll H (1996) Literature on archaeological remains of cultivated plants (1994/1995). Veg Hist Archaeobot 5:169200. doi:10.1007/bf00189448

Lee G-A (2013) Archaeological perspectives on the origins of Azuki (Vigna angularis). Holocene 23(3):453-459. doi: 10.1177/0959683612460788

Lokeshwar RR (ed) (1997) Handbook of agriculture, 5th edn. Indian Council of Agricultural Research, New Delhi

Mallikarjuna N, Savena KB, Jadhav DR (2011) Chapter 2. Cajanus. In: Wild crop relatives: genomic and breeding resources, legume crops and forages. Plant science. Springer, Berlin, pp 21-33

Moles AT, Zackery DD, Twaddle JC, Vickie JB, Smith R, Fleishman MR, Mayfield MM, Pitman A, Wood JT, Westby M (2007) Global patterns in seed size. Global Ecol Biogeogr 16:109-116. doi:10.1111/j.1466-8238. 2006.00259.x

Morris JB, Wang ML, Grusak MA, Tonnis B (2013) Fatty acid, flavonol, and mineral composition variability among seven Macrotyloma uniflorum (Lam.) Verdc. Agriculture 3(1):157-169. doi:10.3390/agriculture3010157

Murphy C, Fuller DQ (2016) Food production in India: South Asian entanglements of domestication. In: Schug GR, Walimbe SR (eds) A companion to South Asia in the past. Wiley Blackwell, Oxford, pp 344-357

Murphy C, Fuller DQ (2017) Seed coat thinning during horsegram (Macrotyloma uniflorum) domestication documented through synchrotron imaging of archaeological seeds. Sci Rep

Murphy C, Fuller DQ (in preparation) Measuring pulse domestication: using morphometrics to study rates of domestication in Macrotyloma uniflorum (Lam.) Verdc

Muthukumara T, Prabua P, Ghosh K, Sastrya TP (2014) Fish scale collagen sponge incorporated with Macrotyloma uniflorum plant extract as a possible wound/burn dressing material. Colloids Surf B 113:207-212. doi:10.1016/j. colsurfb.2013.09.019

Neelam S, Kumar V, Natarajan S, Venkateshwaran K, Pandravada SR (2014) Evaluation and diversity observed in horsegram (Macrotyloma uniflorum (Lam.) Verdc.), India. Plant 4(1):17-22. doi:10.5923/j.plant.20140401.04

Nezamuddin S (1970) Pulse crops of India. Indian Council of Agricultural Research, New Delhi

Ponton C, Giosan L, Eglinton TI, Fuller DQ, Johnson JE, Kumar P, Collett TS (2012) Holocene aridification of India. Geophys Res Lett 39:1-6. doi:10.1029/2011gl 050722
Prakash BG, Channayya P, Hiremath SB, Devarnavdgi Salimath PM (2010) Assessment of genetic diversity among germplasm lines of horsegram (Macrotyloma uniflorum) at Bijapur. EJPB 1(4):414-419

Prasad SK, Singh MK (2015) Horse gram—an underutilized nutraceutical pulse crop: a review. J Food Sci Technol 52 (5):2489-2499. doi:10.1007/s13197-014-1312-Z

Prasad S, Anoop A, Riedel N, Sarkar S, Menzel P, Basavaiah N, Krishnan R, Fuller D, Plessen B, Gaye B, Röhl U, Wilkes H, Sachse D, Sawant R, Wiesner MG, Stebich M (2014) Prolonged monsoon droughts and links to IndoPacific warm pool: a holocene record from Lonar Lake, central India. Earth Planet Sci Lett 391:171-182

Purugganan M, Fuller DQ (2009) The nature of selection during plant domestication. Nature 457:843-848. doi: 10.1038/nature07895

Purugganan MD, Fuller DQ (2011) Archaeological data reveal slow rates of evolution during plant domestication. Evolution 65(1):171-183. doi:10.1111/j.1558-5646.2010. 01093.x

Randhawa MS (1958) Agriculture and animal husbandry in India. Indian Council for Agricultural Research, New Delhi

Reddy SN (1994) Plant usage and subsistence modeling: an ethnoarchaeological approach to the late harappan of Northwest India. Ph.D. thesis. WI: University of Wisconsin, Madison

Reddy SP, Ramanjulu S, Sudhakar C, Veeranjaneyulu K (1998) Differential sensitivity of stomatal and non-stomatal components to $\mathrm{NaCl}$ or $\mathrm{Na}_{2} \mathrm{SO}_{4}$ salinity in horsegram, Macrotyloma uniflorum (Lam.). Photosynthetica 35 (1):99-105. doi:10.1023/A:1006830100627

Reddy PCO, Sairanganayakulu G, Thippeswamy M, Reddy PS, Reddy MK, Sudhakar C (2008) Identification of stressinduced genes from the drought tolerant semi-arid legume crop horsegram (Macrotyloma uniflorum (Lam.) Verdc.) through analysis of subtracted expressed sequence tags. Plant Sci 175(3):372-384. doi:10.1016/j.plantsci. 2008.05.012

Sangita Y, Negi KS, Mandal S (2004) Protein and oil rich wild horsegram. Genet Resour Crop Evol 51:629-633. doi: 10.1023/B:GRES.0000024650.44318.2d

Saraswat KS (1992) Archaeobotanical remains in ancient cultural and socio-economical dynamics of the Indian subcontinent. Palaeobotanist 40:514-545

Saxena RK, von Wettberg E, Upadhyaya HD, Sanchez V, Songok S, Saxena K, Kimurto P, Varshney RK (2014) Genetic diversity and demographic history of Cajanus spp. Illustrated from genome-wide SNPs. PLoS ONE 9 (2):1-9. doi:10.1371/journal.one.0088568

Sharma V, Rana M, Katoch M, Sharma PK, Ghani M, Rana JC, Sharma TR, Chahota RK (2015) Development of SSR and ILP markers in horsegram (Macrotyloma uniflorum), their characterization, cross-transferability and relevance for mapping. Mole Breed 35:102. doi:10.1007/s11032015-0297-2

Singh NP, Singh KP, Singh DK (2002) Flora of mizoram, vol 1. Botanical Survey of India, Kolkata

Smartt J (1985) Evolution of grain legumes. II. Old and New World pulses of lesser economic importance. Exp Agric 21:1-18. doi:10.1017/S0014479700012205 
Smartt J (1990) Grain legumes. Cambridge University Press, Cambridge

Southworth F (2005) The linguistic archaeology of South Asia. Routledge, London

Southworth FC, McAlpin DW (2013) 30 South Asia: Dravidian linguistic history. The Encyclopedia of Global Human Migration. Wiley-Blackwell, Oxford, pp 235-244

Spate OH, Learmonth AT (1967) India and Pakistan, a general and regional geography, 3rd edn. Methuen \& Co.Ltd, London

Sreerama YN, Sasikala VB, Pratape V (2008) Nutritional implications and flour functionality of popped/expanded horse gram. Food Chem 108:891-899. doi: 10.1016/j.foodchem.2007.11.055

Sreerama YN, Sashikala VB, Vishwas PM, Singh V (2012) Nutrients and antinutrients in cowpea and horse gram flours in comparison to chickpea flour: evaluation of their flour functionality. Food Chem 131:462-468. doi: 10.1016/j.foodchem.2011.09.008

Sundararaj DD, Thulasidas G (1993) Botany of field crops, 2nd edn. MacMillan India Limited, New Delhi

Tomooka N, Naito K, Kaga A, Sakai H, Isemura T, OgisoTanaka E, Iseki K, Takahashi Y (2014) Evolution, domestication and neo-domestication of the genus Vigna. Plant Genet Resour 12(S1):S168-S171. doi: 10.1017/s1479262114000483

Turner RL (1966) A comparative dictionary of Indo-Aryan languages. Oxford University Press, Oxford

USDA. USDA Website. http://www.ars-grin.gov/cgi-bin/npgs/ html/taxon.pl?23076\#dist. Accessed 02 Jan 2016

van der Maesen LJG (1986) In: Cajanus DC, Atylosia W (eds) Leguminosae. Agricultural University, Wageningen

Varma VS, Durga KK, Ankaiah R (2013) Assessment of genetic diversity in horse gram (Dolichos uniflorus). Elect J Plant Breed 4(2):1175-1179

Verdcourt B (1970) Studies in the leguminosae-papilionoideae from the 'flora of tropical East Africa' III. Kew Bull 24:379-447. doi:10.2307/4102845

Verdcourt B (1971) "Phaeeoleae." In: Flora of Tropical East Africa, Leguminosae (Part 4), Papilionoidae (2). Crown Agents for Overseas Governments and Administrations, London, pp 503-807

Vishnu M (1989) Forty years of archaeobotanical research in South Asia. Man Environ 14:1-16

Watt G (1889-1893) A dictionary of the economic products of India, vols I-VI. Cosmo Publications, Delhi (1972 reprint)
Watt G (1908) The commercial products of India. John Murray, London

Weber Steven A (1991) Plants and harappan subsistence: an example of stability and change from Rojdi. Westview Press, Boulder

Willcox G (1992) Some Differences between Crops of Near Eastern Origin and those from the Tropics. In: South Asian Archaeology 1989, 14:291-99. Monographs in World Archaeology. Prehistory Press, Madison

Witzel M (2009) South Asian agricultural vocabulary. In: Osada $\mathrm{T}$ (ed) Linguistics, archaeology and the human past, indus project. Research Institute for Humanity and Nature, Kyoto

Xu-xiao Z, Vaughan D, Tomooka N, Kaga A, Xin-wang W, Jian-ping G, Shu-min W (2003) Preliminary study on geographical distribution and evolutionary relationships between cultivated and wild adzuki bean (Vigna angularis var. angularis and var. nipponensis) by AFLP analysis. Plant Genet Resour Charact Util 1(2-3):175-183. doi: 10.1079/pgr200327

Yadav S (1992) The preparation, acceptability and nutritional evaluation of wadi-an indigenous legume fermented product. M. Sc. Thesis. Haryana Agricultural University, Hisar, India

Yadav DS (2002) Pulse crops. Kalyani Publishers, Delhi (Reprint)

Yadav S, Negi KS, Mandal S (2004) Protein and oil rich wild horsegram. Genet Resour Crop Evol 51:629-633. doi: 10.1023/B:GRES.0000024650.44318.2d

Zaman A, Mallick S (1991) Water use and seed yield of horsegram under different moisture regimes and mulches in semi-arid region of Eastern India. J Agron Crop Sci 167:39-42. doi:10.1111/j.1439-037X.1991.tb00931.x

Zide AR, Zide NH (1976) Proto-munda cultural vocabulary: evidence for early agriculture. Ocean Linguist Spec Publ 13:1295-1334

Zohary D, Hopf M, Weiss E (2012) Domestication of plants in the Old World: the origin and spread of domesticated plants in South-West Asia, Europe, and the Mediterranean Basin, 4th edn. Oxford University Press, Oxford

Zong XX, Kaga A, Tomooka N, Wang XW, Han OK, Vaughan D (2003) The genetic diversity of the Vigna angularis complex in Asia. Genome 46(4):647-658. doi:10.1139/g03-41 